\title{
Genetic improvements in New Zealand forage cultivars
}

\author{
D.R. WOODFIELD \\ AgResearch Grasslands, Private Bag 11008, Palmerston North
}

\begin{abstract}
Substantial genetic gains have been achieved across a range of temperate forage grass and legume species in New Zealand during the past 60 years. The genetic gains reported here compare favourably with those achieved in cereals and with those achieved for similar species internationally. Substantial improvements in grain yield of cereal crops have been achieved through changes in harvest index; however, increases in yield of forage grasses and legumes reflect increases in total above ground biomass. Rates of genetic gain have been lower in lucerne (Medicago sativa L.) than in red clover (Trifolium pratense L.) and white clover (Trifolium repens L.) and lower in perennial ryegrass (Lolium perenne L.) than in annual ryegrass (Lolium multiflorum Lam.) and tall fescue (Festuca arundinacea Schreb.). Gains in forage yield and quality have often exceeded $1 \%$ per year and have led to significant ( 0.3 to $1.3 \%$ per year) increases in animal performance.
\end{abstract}

Keywords: animal performance, forages, genetic improvement, quality, symbiotic associations, yield

\section{Introduction}

The slow adoption of new pasture species and cultivars in New Zealand has been well documented (Belgrave et al. 1991; Lancashire 1985), with farmers often preferring to sow older cultivars such as Ruanui and Grasslands Nui perennial ryegrass (Lolium perenne L.) and Grasslands Huia white clover (Trifolium repens L.). A common reason reported by both farmers and farm advisors is uncertainty that the increased cost of seed, and the more demanding management requirements, will be offset by improved on-farm profitability (C. Brown pers. comm.). Plant breeders have also failed to clearly demonstrate to farmers and advisors the genetic gains made in pasture performance and the management changes necessary to capitalise on the increased genetic potential of modern cultivars.

Internationally, the rate of genetic improvement has consistently exceeded $1 \%$ per year in the major cereal crops (Fehr 1984; Russell 1991); however, few estimates have been published for forage crops. In forages, genetic gains from breeding efforts can be achieved in various ways including improved annual or seasonal yield, better reliability, increased persistence, improved forage quality, improved animal performance, better animal health, and even through enhanced symbiotic associations.

This paper reports genetic gains achieved in temperate forage species currently being used in New Zealand pastoral systems.

\section{Methods}

Previously published data comparing newer cultivars with long-standing control cultivars have been used to estimate genetic improvements achieved in a range of temperate forage grasses and legumes. Where the same control variety was present in a number of experiments, data has been combined using performance relative to the control variety $(=100 \%)$.

Linear regression (SAS Proc. Reg.) of cultivar performance on the year of release was performed to estimate the genetic gain with time. The absolute rates (\%) of genetic gain were calculated by dividing the regression slope (b) by the mean performance of all cultivars in each experiment or group of experiments. Genetic improvements calculated in this manner are more conservative than if the performance relative to the earliest control varieties had been used.

\section{Results and discussion}

\section{Annual forage yield}

The annual forage yields of three major forage grasses; perennial ryegrass, annual ryegrass (Lolium multiflorum Lam.), and tall fescue (Festuca arundinacea Schreb.), have improved by between 0.25 and $1.18 \%$ annually (Table 1). Genetic improvement was slower in perennial ryegrass than annual ryegrass and tall fescue (Table 1). When Pennell et al. (1990) used Nui as their benchmark cultivar, more recent cultivars showed almost no improvement in total yield. However, when Ruanui was used as the benchmark cultivar, newer cultivars did show significant $(0.6 \%$ per year) improvement (Kerr et al. 1987). Recent data from Thom et al. (1998) also confirm genetic improvement for forage yield in recent 
Table 1 Genetic improvements in annual forage yield of temperate forage grass and legume species.

\begin{tabular}{|c|c|c|c|c|}
\hline Species & $\begin{array}{l}\text { Benchmark } \\
\text { cultivar }\end{array}$ & No. of trials/cultivars & $\begin{array}{c}\text { Genetic gain } \\
(\% / y r)\end{array}$ & Reference \\
\hline Annual ryegrass & G. Moata & 16 trials (11 cvs) & 1.18 & Easton 1997 \\
\hline Perennial ryegrass & $\begin{array}{l}\text { G. Nui } \\
\text { Ruanui } \\
\text { G. Nui }\end{array}$ & $\begin{array}{l}7 \text { trials ( } 8 \text { cvs }) \\
8 \text { trials (Ellett, G. Nui,Yatsyn- } 1) \\
1 \text { trial }(7 \mathrm{cvs})\end{array}$ & $\begin{array}{l}0.25 \\
0.60 \\
0.73\end{array}$ & $\begin{array}{l}\text { Pennell } 1990 \\
\text { Kerr } 1987 \\
\text { Thom et al. } 1998\end{array}$ \\
\hline Tall fescue & G. Roa & 1 trial (G. Advance) & 0.98 & Fraser 1994 \\
\hline Lucerne & Wairau & 3 trials (5 NZ cvs) & 0.35 & G. Purves unpub. data \\
\hline Red clover & $\begin{array}{l}\text { G. Turoa } \\
\text { G. Hamua }(2 x) \\
\text { G. Pawera }(4 x)\end{array}$ & $\begin{array}{l}1 \text { trial (G. Hamua, G. Pawera) } \\
1 \text { trial }(\text { G. Colenso }(2 \mathrm{x})) \\
1 \text { trial }(\mathrm{G} 27(4 \mathrm{x}))\end{array}$ & $\begin{array}{l}0.43 \\
0.21 \\
1.39\end{array}$ & $\begin{array}{l}\text { Anderson } 1973 \\
\text { Claydon } 1993 \\
\text { Rumball } 1997\end{array}$ \\
\hline White clover & $\begin{array}{l}\text { G. Huia } \\
\text { G. Huia }\end{array}$ & 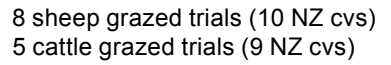 & $\begin{array}{l}1.49 \\
1.21\end{array}$ & $\begin{array}{l}\text { Woodfield } 1999 \\
\text { Woodfield } 1999\end{array}$ \\
\hline
\end{tabular}

perennial ryegrass cultivars. Annual yield increased by $0.73 \%$ per year, with much of this improvement being associated with better crown rust resistance in newer cultivars (Table 1). These improvement rates are similar to those reported for perennial ryegrass $(0.5 \%$ per year $)$ in Europe (van Wijk \& Reheul 1991). The discovery of endophyte's role in ryegrass pest resistance and persistence in the 1980s probably accounts for some of the reduced progress in improving perennial ryegrass yield.

The $1.18 \%$ increase in annual ryegrass annual yield was almost double that reported for annual ryegrass (0.5\% per year) in Europe (van Wijk \& Reheul 1991). Further evidence of genetic improvement in annual ryegrass yield can be observed from the performance of G. Moata, the control cultivar used by Easton et al. (1997). G. Moata was consistently amongst the poorest performing cultivars for seasonal and annual yield (Easton et al. 1997), however, when it was first released it yielded $15-20 \%$ better than the next best annual ryegrass (Rumball \& Armstrong 1975).

Genetic gains in forage yield were generally higher for legumes with simpler genetic inheritance (white clover and red clover (Trifolium pratense L.)) than in those with more complex genetics such as lucerne (Medicago sativa L.) (Table 1). A rate of genetic gain of $0.6 \%$ per year for both white clover yield and clover content has been reported previously from an international collection of 110 white clover cultivars grown in New Zealand (Woodfield \& Caradus 1994). The majority of these cultivars were not adapted to New Zealand conditions, and hence probably underestimated the true genetic gains achieved. The performance of New Zealand bred cultivars in eight trials under sheep grazing and five trials under cattle systems indicate that genetic gains have exceeded $1 \%$ per year for annual forage yield (Table 1). Genetic improvement in white clover yield appears to have been more rapid over the
Figure 1 Forage yield of New Zealand bred white clover cultivars in eight trials under sheep grazing. Yield is expressed relative to the performance of Grasslands Huia (=100\%).

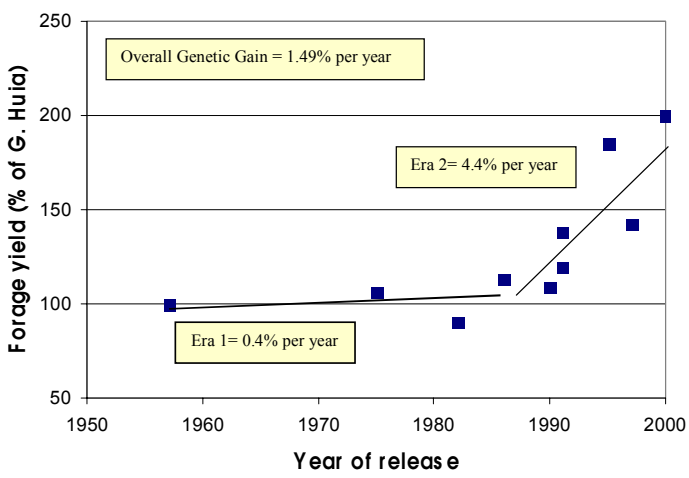

Figure 2 Forage yield of New Zealand bred white clover cultivars in five trials under cattle grazing. Yield is expressed relative to the performance of Grasslands Huia $(=100 \%)$.

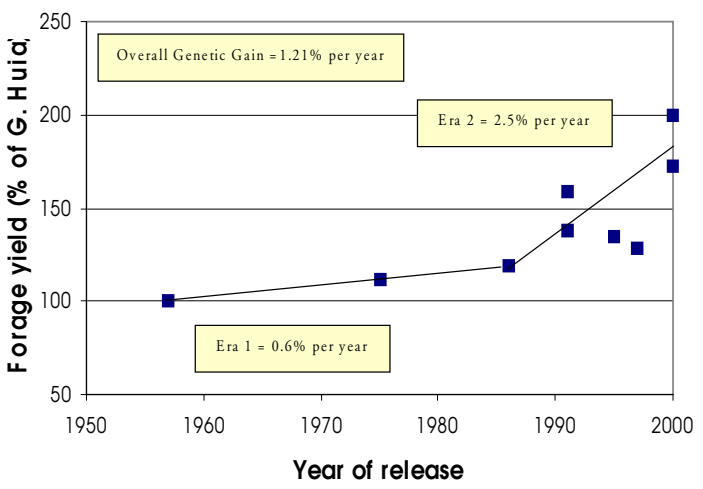

past decade (Figures 1 and 2). The genetic improvement under sheep grazing has increased from $0.4 \%$ per year before 1985 , to more than $4 \%$ per year since 1985 (Figure 1). Similarly, the genetic improvement under 
cattle grazing has increased from $0.6 \%$ per year before 1985 , to $2.5 \%$ per year since 1985 (Figure 2). While these higher rates are probably overestimated due to newer cultivars being present in fewer trials, there is little doubt that the rate of genetic improvement has increased since 1985. Before 1985, the white clover cultivars bred and released in New Zealand had to be broadly adapted to sheep and cattle grazing from Northland to Southland. However, since 1985, cultivars have been released for specific environments and management systems; for example, G. Demand was bred for Southern New Zealand sheep grazing. Increased rates of genetic improvement may also be due to additional resources (funding and staffing) put into white clover breeding since the early 1980 s.

The estimates of genetic gain in red clover forage yield varied from $0.21 \%$ to $1.39 \%$ per year (Table 1 ). However, the lower estimate calculated from Claydon (1993), is artificially low because the breeding of G. Colenso was completed nearly 20 years before it was actually released (Claydon pers. comm.).

The rate of genetic gain in New Zealand lucerne cultivars was similar to results reported in North America (Hill et al. 1988; Holland \& Bingham 1994) but was not statistically significant $(\mathrm{P}>0.6)$.

Substantial improvements in grain yield of cereal crops have been achieved through changes in harvest index; however, increases in yield of forage grasses and legumes reflect increases in total above ground biomass. Minimal changes in harvest index are possible by reducing the proportion of DM which is below ground but there are limits to the plants abilities to do this without sacrificing agronomically important traits such as persistence, drought tolerance and nutrient uptake.

\section{Seasonal forage yield}

While increases in annual forage yield are important, annual yield has frequently been sacrificed in breeding programmes in order to improve seasonal yield and/or reliability of that yield. Increases in seasonal yield are aimed at meeting animal requirements at key times such as lamb finishing and post-Christmas yield in dairying. The majority of genetic improvement in annual ryegrass yield was associated with increased seasonal yield. Seasonal increases of up to $3.6 \%$ per year in summer and in the $2^{\text {nd }}$ autumn were far in excess of those reported for annual yield (Table 2). In perennial ryegrass, Pennell et al. (1990) reported significantly higher forage yields in summer and winter for G. Pacific, despite annual yield not being improved compared to the controls. Similarly, much of the improvement in performance of Yatsyn- 1 was associated with improved autumn $(0.94 \%$ per year) and winter $(0.85 \%$ per year) growth (Kerr 1987).

In both red clover and white clover, seasonal yield improvements have been reported. G. Colenso red clover and G. Challenge white clover are examples, having both been bred for improved winter and early-spring growth (Claydon et al. 1993; Cooper et al. 1997).

\section{Animal performance and health}

Improvements of between $0.3 \%$ and $1.4 \%$ per year in animal growth rates and stocking rate have been reported for several forage species (Table 3). These rates were lower than the comparable increases in forage yield and quality for each species, with the exception of the increased liveweight gains from newer perennial ryegrass cultivars. The increased animal performance on recent ryegrass cultivars was partially explained by increased forage yield but also reflects differences in forage quality

Table 2 Genetic improvement in seasonal yield of annual ryegrass (derived from Easton et al. (1997) data; 11 cultivars with yield from between 7 and 16 trials).

\begin{tabular}{|c|c|c|c|c|c|c|}
\hline & $1^{\text {st }}$ Autumn & Winter & $\begin{array}{c}\text { Season } \\
\text { Spring }\end{array}$ & Summer & $2^{\text {nd }}$ Autumn & $\begin{array}{c}\text { Annual } \\
\text { Yield }\end{array}$ \\
\hline Genetic gain (\%/yr) & -0.17 & 0.06 & 0.36 & 2.67 & 3.61 & 1.18 \\
\hline$P<0.05$ & NS & NS & NS & * & * & * \\
\hline
\end{tabular}

Table 3 Genetic improvements in forage quality and animal performance of temperate forage grass and legume species.

\begin{tabular}{llcccc}
\hline Species & Trait & $\begin{array}{c}\text { Benchmark } \\
\text { cultivar }\end{array}$ & $\begin{array}{c}\text { Cultivars } \\
\text { (\%/yr) }\end{array}$ & Genetic gain & Reference \\
\hline Perennial ryegrass & Lamb liveweight gain & G. Nui & HD Aries, Quartet & 1.37 & Westwood 1999 \\
Tall fescue & Lamb growth rate & G. Roa & G. Advance & 0.87 & Fraser 1994 \\
Red clover & Formonenetin & G. Pawera (4x) & G27 (4x) & 2.83 & Rumball 1997 \\
White clover & Lamb growth rate & G. Huia & G. Demand & $0.33^{\pi}$ & $\begin{array}{l}\text { Ryan 1997 } \\
\end{array}$ \\
& Lamb growth rate & G. Huia & G. Tahora & 0.48 & Chapman 1993 \\
& Stocking rate & G. Huia & G. Tahora & 0.32 & Chapman 1993 \\
\hline
\end{tabular}

$\pi$ Genetic gains for Demand were calculated over a 23 year period from the initiation of the breeding programme to cultivar release 
and in the associated endophyte strain (Westwood \& Norriss 1999). Improvements in disease resistance, such as improved crown rust resistance in newer perennial ryegrass cultivars, can also contribute to improved forage yield and forage quality, while reducing costly pesticide inputs.

Achieving animal production responses from forage improvement relies upon the ability to utilise the additional feed produced. This often requires higher stocking rates and better grazing management. Other on-farm benefits can also be realised where reductions in supplementary feeding requirements occur, and/or when animal health is improved through better nutrition or elimination of an anti-quality factor. Low formononetin red clover is a prime example of breeding successfully reducing an anti-quality trait. Selection for lower levels of formononetin achieved genetic improvements of $2.8 \%$ per year (Table 3 ) and resulted in substantially higher ovulation rates in ewes grazing red clover (cited by Rumball et al. 1997).

\section{Symbiotic associations}

Nitrogen fixation and the grass-endophyte association are two key symbiotic associations affecting forage yield and animal performance in New Zealand. Analysis of three trials, in which $\mathrm{N}^{15}$ techniques were used to compare the $\mathrm{N}$ fixation potential of old and new white clover cultivars, indicated $\mathrm{N}$ fixation had increased by $1.2 \%$ genetic gain per year (Woodfield 1999). This increase in $\mathrm{N}$ fixation is an indirect response to selection for forage yield as there has not been any direct selection for $\mathrm{N}$ fixation in the white clover cultivars tested.

The improvement of perennial ryegrass and tall fescue performance by selection of improved endophyte strains has been reviewed by Fletcher \& Easton (1997). Liveweight gain of lambs was reduced from $102 \mathrm{~g} /$ day on endophyte-free ryegrass to only $35 \mathrm{~g} /$ day when grazing ryegrass infected with wild-type endophyte. Endophyte does however contribute both drought tolerance and resistance to invertebrate pests. Efforts are underway to develop novel endophytes which combine these benefits with the improved animal performance of endophyte-free grasses (Fletcher \& Easton 1997).

\section{Summary}

The genetic gains reported here compare favourably with those achieved in the major cereals such as maize (Russell 1991) and with those achieved for similar species internationally. Substantial improvements in grain yield of cereal crops have been achieved through changes in harvest index, however, increases in yield of forage grasses and legumes reflect increases in total above ground biomass. Genetic gains in annual forage yield, seasonal forage yield, and forage quality have been achieved for both grasses and legumes. These improvements have resulted in increased animal performance, although at lower rates than the comparable increases in plant performance. Further research is required to determine the economic benefits these improvements provide to the New Zealand pastoral industry.

\section{REFERENCES}

Anderson, L.B. 1973. Relative performance of the lateflowering tetraploid red clover 'Grasslands 4706', five diploid red clovers, and white clover. New Zealand journal of experimental agriculture 1: 233237

Belgrave, B.R.; Watt, P.C.; Brock, J.L.; Wewala, S.; Sedcole, J.R. 1990. A survey of farmer knowledge and use of pasture cultivars in New Zealand. New Zealand journal of agricultural research 33: 199211.

Chapman, D.F.; Caradus, J.R. 1997. Effects of improved, adapted white clover (Trifolium repens L.) germplasm on the productive properties of a hill pasture. New Zealand journal of agricultural research 40: 207-221.

Chapman, D.F.; Mackay, A.D.; Devantier, B.P.; Dymock, N. 1993. Impact of white clover cultivars on nitrogen fixation and livestock production in a New Zealand hill pasture. Proceedings of the XVII International Grassland Congress: 420-421.

Claydon, R.B.; Miller, J.E.; Anderson, L.B. 1993. Breeding of a winter-growing red clover $-\mathrm{cv}$. Grasslands Colenso (Trifolium pratense L.). New Zealand journal of agricultural research 36: 297-300.

Cooper, B.M.; Clifford, P.T.P.; Williams, W.M. 1997. Development of white clover (Trifolium repens L.) cultivar Grasslands Challenge (G23). Proceedings New Zealand Grassland Association 59: 99-102.

Easton, S.; Baird, D.; Baxter, G.; Cameron, C.; Hainsworth, R.; Johnston, C.; Kerr, G.; Lyons, T.; McCabe, R.; Nichol, W.; Norriss, M.; Stewart, A.; Thom, E. 1997. Annual and hybrid ryegrass cultivars in New Zealand. Proceedings New Zealand Grassland Association 59: 239-244.

Fehr, W.R. 1984. Genetic contributions to yield gains of five major crop plants. CSSA Special Publication 7. Wisconsin, Crop Science Society of America. $101 \mathrm{pp}$.

Fletcher, L.R.; Easton, H.S. 1997. The evaluation and use of endophytes for pasture improvement. pp. 209-227. In: Neotyphodium/Grass Interactions. Eds. Bacon, C.W.; Hill, N.S. New York, Plenum Press. 
Fraser, T.J.; Lyons. T.B. 1994. Grasslands Advance tall fescue establishment and animal performance. Proceedings New Zealand Grassland Association 56: 117-119.

Hill, R.R.; Shenk, J.S.; Barnes, R.F. 1988. Breeding for yield and quality. Agronomy monograph 29: 809825.

Holland, J.B.; Bingham, E.T. 1994. Genetic improvement for yield and fertility of alfalfa cultivars representing different eras of breeding. Crop science 34: 953-957.

Kerr, G.A. 1987. Evaluation of four perennial ryegrass cultivars in New Zealand. Proceedings New Zealand Grassland Association 48: 137-141.

Lancashire, J.A. 1985. Some factors affecting the rate of adoption of new herbage cultivars. In: Using Herbage Cultivars. Eds. Burgess, R.E.; Brock, J.L. Grassland Research and Practice Series No. 3: 7987.

Pennell, C.G.L.; Easton; H.S.; Goold, G.; Hay, R.; Hickey, M.; Hoglund, J.; Lyons, T.; McCallum, D.; Paewai, H.; Stevens, D.; Thomson, N.; Woods, P. 1990. 'Grasslands Pacific' perennial ryegrass: performance at several sites. Proceedings New Zealand Grassland Association 52: 151-155.

Rumball, W.; Armstrong, C.S. 1975. The performance of overseas ryegrass cultivars in New Zealand. Proceedings New Zealand Grassland Association 36: $97-104$
Rumball, W.; Keogh, R.G.; Miller, J.E.; Claydon, R.B. 1997. New Zealand journal of agricultural research 40: 369-372.

Russell. W.A. 1991. Genetic improvement of maize yields. Advances in agronomy 46: 245-298.

Ryan, D.L.; Widdup, K.H. 1997. Lamb and hogget growth on different white clover and ryegrass cultivar mixtures in Southern New Zealand. Proceedings New Zealand Society of Animal Production 57: 182185.

Thom, E.R.; Waugh, C.D.; McCabe, R.J. 1998. Growth and persistence of perennial and hybrid ryegrasses when grazed by dairy cows in the central Waikato region of New Zealand. New Zealand journal of agricultural research 41: 477-486.

van Wijk, A.J.P.; Reheul, D. 1991. Achievements in fodder crops breeding in maritime Europe. Proceedings of Meeting of the Fodder Crops Section of Eucarpia 16: 13-18.

Westwood, C.T.; Norriss, M.G. 1999. Liveweight changes in lambs grazing six perennial ryegrass cultivars. Proceedings New Zealand Grassland Association 61: 31-35.

Woodfield, D.R.; Caradus, J.R. 1994. Genetic improvement in white clover representing six decades of plant breeding. Crop science 34: 1205-1213.

Woodfield, D.R. 1999. Genetic gains in performance of New Zealand white clover varieties. New Zealand journal of agricultural research (submitted). 
